\title{
Thermogravimetric Analysis of the Combustion of Khakassia Coal, Pine Sawdust and their Blends
}

\author{
Andrei V. Zhuikov*a, \\ Anatoly I. Matiushenko ${ }^{\text {, Petr N. Kuznetsov }}{ }^{\text {, }}$ \\ Olesya P. Stebeleva ${ }^{a}$ and Alexander S. Samoilo ${ }^{a}$ \\ a Siberian Federal University \\ Krasnoyarsk, Russian Federation \\ ${ }^{b}$ Institute of Chemistry and Chemical Technology SB RAS \\ Krasnoyarsk, Russian Federation
}

Received 12.07.2021, received in revised form 14.08.2021, accepted 21.09.2021

\begin{abstract}
A thermogravimetric analysis (TGA) of the combustion of two long-flame hard coals from the Republic of Khakassia, pine sawdust and their blends in the air stream, depending on the chemical composition and thermal characteristics of the samples, was carried out. The ignition temperature and the burn-out temperature of the coke residue of the studied samples were determined by extrapolation using the TG and DTG curves. The indices of ignition, burnout and combustion are calculated taking into account the time parameters. The ignition temperature of pine sawdust was $T_{i}=308^{\circ} \mathrm{C}$, the burnout temperature was $\mathrm{T}_{\mathrm{b}}=490^{\circ} \mathrm{C}$. When sawdust was added to the coals, the combustion process of the blend shifted to lower temperatures, and the ignition temperature decreased by more than $100{ }^{\circ} \mathrm{C}$ compared to the ignition temperature of the coals. The energy -efficient compositions of blends that ensure their high combustion characteristics are determined.
\end{abstract}

Keywords: hard coal, biomass, mixed fuel, thermogravimetric analysis.

Citation: Zhuikov A. V., Matiushenko A.I., Kuznetsov P.N., Stebeleva O. P., Samoilo A.S. Thermogravimetric analysis of the combustion of Khakassia coal, pine sawdust and their blends, J. Sib. Fed. Univ. Eng. \& Technol., 2021, 14(6), 611-622. DOI: $10.17516 / 1999-494 X-0338$

(C) Siberian Federal University. All rights reserved

This work is licensed under a Creative Commons Attribution-Non Commercial 4.0 International License (CC BY-NC 4.0).

* Corresponding author E-mail address: azhuikov@sfu-kras.ru 


\title{
Термогравиметрический анализ
}

\section{горения каменных углей Республики Хакасия, сосновых опилок и их смесей}

\author{
А.В. Жуйков ${ }^{\mathrm{a}}$, А.И. Матюшенко \\ П.Н. Кузнецов \\ ${ }^{a}$ Сибирский федеральный университет \\ Российская Федераиия, Красноярск \\ ${ }^{6}$ Институт химии и химической технологии \\ ФИЦ КНЦ СО РАН \\ Российская Федерачия, Красноярск
}

\begin{abstract}
Аннотация. Проведен термогравиметрический анализ (ТГА) горения в потоке воздуха двух длиннопламенных каменных углей из Республики Хакасия, сосновых опилок и их смесей в зависимости от химического состава и теплотехнических характеристик образцов. По кривым ТГ и ДТГ методом экстраполяции определены температура воспламенения и температура выгорания коксового остатка исследуемых образцов. С учетом временных параметров рассчитаны индексы воспламенения, выгорания и горения. Температура воспламенения сосновых опилок составила $\mathrm{T}_{\mathrm{i}}=308^{\circ} \mathrm{C}$, температура выгорания $\mathrm{T}_{\mathrm{b}}=490^{\circ} \mathrm{C}$. При добавлении опилок к каменным углям процесс горения смеси смещается в сторону более низких температур, а температура воспламенения снизилась более чем на $100{ }^{\circ} \mathrm{C}$ по сравнению с температурой воспламенения каменных углей. Установлены энергоэффективные составы смесей, обеспечивающих их высокие характеристики горения.
\end{abstract}

Ключевые слова: каменный уголь, биомасса, смесевое топливо, термогравиметрический анализ.

Цитирование: Жуйков, А.В. Термогравиметрический анализ горения каменных углей Республики Хакасия, сосновых опилок и их смесей / А. В. Жуйков, А. И. Матюшенко, П.Н. Кузнецов, О. П. Стебелева, А. С. Самойло // Журн. Сиб. федер. ун-та. Техника и технологии, 2021, 14(6). C. 611-622. DOI: 10.17516/1999-494X-0338

\section{Введение}

Наиболее распространенный и дешевый способ получения тепловой и электрической энергии основан на сжигании угля на теплоэлектростанциях. В процессе горения в атмосферу городов выбрасывается большое количество твердых и газообразных продуктов, включая парниковые газы, с которыми связывают глобальное потепление. Применение смесей твердых топлив на теплоэлектростанциях может улучшить экологические характеристики, а также снизить общий расход угля [1]. Добавочными твердыми топливами могут являться торф, бурый уголь, каменный уголь, антрацит, альтернативные виды топлив (отходы переработки древесины, отходы сельскохозяйственных предприятий, сухие остатки сточных вод, твердые коммунальные отходы), а также искусственные виды топлива (древесные или угольные пеллеты, брикеты и т. п.) [2-4].

Для использования биомассы в качестве энергетического топлива применяют разные способы: сжигание, газификация, пиролиз, торрефикация. Наиболее распространенным является сжигание. При изучении процесса горения биомассы чаще всего используют метод термогравиметрического анализа $[5,6]$. Выполненные исследования показали, что сжигание смеси лигнита и биомассы позволяет улучшить характеристики горения, в том числе достигать более высокой максимальной скорости горения. Отмечены некоторые эффекты синергизма при горе- 
нии смесевого топлива [7]. С применением термогравиметрического анализа установлено, что при добавлении древесных опилок к каменному углю снижалась температура воспламенения. По данным [9], воспламенение смеси сосновых опилок с каменным углем происходило при температуре, близкой к температуре воспламенения опилок. При оптимальном составе смеси (70 \% каменного угля и 30 \% древесных опилок) достигалось также существенное уменьшение количества выбросов [8]. Авторы [10] изучали процесс сжигания смесевого топлива на основе горючего сланца с добавлением биомассы. Термогравиметрический анализ процесса горения осуществляли при высоких скоростях нагрева $\left(100,500\right.$ и $\left.1000{ }^{\circ} \mathrm{C}\right)$. Было установлено, что горение смеси в указанных условиях происходит в две температурные стадии, которые связаны с раздельным горением компонентов смеси. При этом зона горения сланца смещалась к более низкой температуре.

В последние десятилетия опубликованы результаты большого количества исследований, которые посвящены изучению процессов горения топливных смесей на основе углей с различными добавками, включая биомассу. Вместе с тем исследования топливных смесей, основу которых составляют компоненты биомассы, в частности отходы переработки древесины, весьма ограничены. В Сибири переработка древесины осуществляется в крупных масштабах, при этом на предприятиях накапливается значительное количество древесных отходов, которые пожароопасны, продукты гниения представляют экологическую опасность для окружающей среды. Это определяет необходимость разработки эффективных способов рационального использования отходов с получением полезных продуктов. Одно из направлений включает вовлечение древесных отходов в топливный баланс предприятий и регионов.

Целью данной работы является проведение комплексного термического анализа с использованием дифференциальной сканирующей калориметрии (ТГ/ДТГ/ДСК) для исследования характеристик горения двухкомпонентных топливных смесей на основе каменных углей с добавлением биомассы и топливных смесей на основе биомассы с добавлением каменного угля двух разных марок.

\section{Характеристики образцов и методы исследования}

В работе в качестве объектов исследования использованы два образца длиннопламенных каменных углей и образцы сосновых опилок:

1. Изыхский длиннопламенный каменный уголь (ИЗ), Изыхский угольный разрез, Россия;

2. Черногорский длиннопламенный каменный уголь (Ч), Черногорский угольный разрез, Россия;

3. Сосновые опилки (ОП), Россия.

Каменные угли (ИЗ, Ч) используются как основное энергетическое топливо для промышленно-отопительных котельных в Республике Хакасия. Древесные опилки (ОП) были отобраны на деревообрабатывающем предприятии г. Красноярска.

Характеристики образцов изучены после достижения ими состояния аналитической пробы, влажность которой доведена до состояния равновесия с влажностью воздуха в лабораторном помещении. Образцы каменных углей и опилок с начальным размером менее 20 мм по отдельности измельчали в дисковой мельнице Retsch DM 200 (Retsch GmbH, Germany). Ее основные 
характеристики: максимальный начальный размер частиц менее 20 мм, максимальное число оборотов 528 об/мин, гарантированная тонина помола менее 100 мкм. Для подготовки экспериментальных образцов использовалась аналитическая просеивающая машина Retsch AS200 BASIC (Retsch GmbH, Germany) с двумя ситами, размер ячеек которых составлял 53 и 200 мкм. Таким образом, получались образцы угля и сосновых опилок с размерами частиц 53-200 мкм, что соответствует размерам пылеугольного топлива, используемого при факельном сжигании в энергетических котлах [11]. Калорийность топливных образцов определяли в калориметре IKA C6000. Влажность устанавливали по ГОСТ 8.649-2015, зольность - по ГОСТ 55661-2013, выход летучих веществ - по ГОСТ R55660-2013, содержание серы - по ГОСТ 32979-2014, высшая теплота сгорания - по ГОСТ 147-2013, содержание углерода, водорода, азота, серы по ГОСТ 32979-2014, содержание кислорода - по ГОСТ 27313-2015. Основные характеристики топливных образцов приведены в табл. 1.

Изыхский каменный уголь имеет теплоту сгорания $\mathrm{Q}_{\mathrm{s}}{ }^{\mathrm{daf}}=31,89 \mathrm{MДж/кг,} \mathrm{V}^{\mathrm{daf}}=39,2 \%$, содержание серы в нем равно $0,8 \%$. Черногорский каменный уголь имеет теплоту сгорания 25,48 МДж/кг, $\mathrm{V}^{\mathrm{daf}}=44,0 \%$, содержание серы в образце составило 0,8 \%. Минеральный состав проб углей представлен в основном кварцем (48,4-63,5\%), муллитом (7,3-25,7 \%), альбитом (7-7,8 \%) и плагиоклазом (19-21,5 \%). Содержание $\mathrm{CaO}$ составляет от 3 до 5 \%. Сосновые опилки имеют теплоту сгорания $\mathrm{Q}_{\mathrm{s}}^{\mathrm{daf}}=22,04 \mathrm{MДж/кг,} \mathrm{V}^{\mathrm{daf}}=80,2 \%$, содержание серы в опилках обнаружено не было.

Термический анализ образцов проводили с применением синхронного термоанализатора SDT Q600 (TA Instruments-Waters LLC, New Castle, DE, USA), совмещенного с ИК-Фурье спектрометром Nicolet380 c TGA/FT-IR интерфейсом (приставка для анализа газовой фазы). Кривые ТГ, ДТГ, ДСК и ДТА снимали для навесок топлив массой $6,0 \pm 0,25$ мг в потоке воздуха с расходом 50 мл/мин при скорости нагрева $20^{\circ} \mathrm{C} /$ мин. Основные характеристики процессов горения определяли путем анализа термогравиметрических кривых, полученных из Universal Analysis 2000 (программное обеспечение V5.5.24 от TA Instruments-Waters LLC, New Castle, DE, USA).

Электронно-микроскопические (СЭМ) исследования проводили на сканирующем электронном микроскопе TM4000 (Hitachi, Япония), оборудованном энергодисперсионным спектрометром и системой рентгеновского микроанализа Quantax150 (Bruker, Германия) в режиме низкого вакуума (без напыления платины).

По данным термогравиметрического анализа горения углеродного остатка ИЗ, Ч, ОП и их смесей определяли следующие характеристики горения: индекс воспламенения $\left(\mathrm{D}_{\mathrm{i}}\right)[12$,

Таблица 1. Технические характеристики и элементный состав образцов

Table 1. Technical characteristics and elemental composition of samples

\begin{tabular}{|c|c|c|c|c|c|c|c|c|c|}
\hline \multirow{2}{*}{ Образец } & \multirow{2}{*}{$\mathrm{W}_{\mathrm{t}}^{\mathrm{a}}, \%$} & \multirow{2}{*}{$\mathrm{A}^{\mathrm{d}, \%}$} & \multirow{2}{*}{$\mathrm{V}^{\mathrm{daf}}, \%$} & \multicolumn{5}{|c|}{ Элементный состав, мас\% на daf } & \multirow{2}{*}{$\begin{array}{c}\mathrm{Q}_{\mathrm{s}}^{\text {daf }} \\
\text { МДж/кг }\end{array}$} \\
\hline & & & & $\mathrm{C}$ & $\mathrm{H}$ & $\mathrm{N}$ & $\mathrm{S}$ & $\mathrm{O}$ & \\
\hline ИЗ & 5,0 & 15,9 & 39,2 & 78,2 & 5,0 & 2,2 & 0,8 & 13,8 & 31,89 \\
\hline Ч & 4,7 & 17,8 & 44,0 & 75,0 & 4,9 & 2,0 & 0,6 & 17,5 & 31,07 \\
\hline ОП & 2,8 & - & 80,2 & 55,6 & 5,5 & 0,3 & - & 38,6 & 22,04 \\
\hline
\end{tabular}

Примечание. $\mathrm{W}_{\mathrm{t}}^{\mathrm{a}}$ - массовая доля влаги образца, $\mathrm{A}^{\mathrm{d}}$ - зольность, $\mathrm{V}^{\mathrm{daf}}-$ выход летучих веществ, $\mathrm{Q}_{\mathrm{s}}^{\mathrm{daf}}-$ теплота сгорания. 
13], индекс выгорания $\left(\mathrm{D}_{\mathrm{b}}\right)[14,15]$ и индекс горения $(\mathrm{S})[16,17]$. Индекс воспламенения $\left(\mathrm{D}_{\mathrm{i}}\right)$ отображает динамику воспламенения углеродного остатка. Индекс выгорания $\left(\mathrm{D}_{\mathrm{b}}\right)$ характеризует степень выгорания углеродного остатка. Низкая скорость и высокая температура выгорания углеродного остатка характерны для топлив, подверженных неполному выгоранию и спеканию. Индекс горения (S) применяется для сравнения горючести разных образцов топлив и включает в себя воспламенение, горение и выгорание углеродного остатка. Высокое значение индекса горения характерно для топлив с высокими параметрами горения углеродного остатка. Расчет индексов воспламенения, выгорания и горения производился по формулам (1-3):

$$
\mathrm{D}_{\mathrm{i}}=\frac{\mathrm{R}_{\max }}{\left(\mathrm{t}_{\mathrm{i}} \cdot \mathrm{t}_{\max }\right)}
$$

где $\mathrm{R}_{\max }$ - максимальная скорость потери массы, $\mathrm{t}_{\mathrm{i}}$ и $\mathrm{t}_{\max }$ - время воспламенения и время, соответствующее максимальной скорости потери массы.

$$
D_{b}=\frac{R_{\max }}{\left(\Delta t_{1 / 2} \cdot t_{\max } \cdot t_{b}\right)},
$$

где $\Delta \mathrm{t}_{1 / 2}-$ временной интервал ДТГ; $\mathrm{R}_{\max }=0,5$ по обе стороны от самого высокого пика кривой ДТГ; $\mathrm{t}_{\mathrm{b}}-$ время выгорания.

$$
\mathrm{S}=\frac{\left(\mathrm{R}_{\max } \cdot \mathrm{R}_{\text {mean }}\right)}{\left(\mathrm{T}_{\mathrm{i}}^{2} \cdot \mathrm{T}_{\mathrm{b}}\right)}
$$

где $\mathrm{R}_{\text {mean }}$ - средняя скорость потери массы (от воспламенения до выгорания топливных образцов); $\mathrm{T}_{\mathrm{i}}$ и $\mathrm{T}_{\mathrm{b}}$ - температура воспламенения и температура выгорания топливных образцов.

Для вычисления значений $\mathrm{D}_{\mathrm{i}}, \mathrm{D}_{\mathrm{b}}$ и $\mathrm{S}$ по кривым ТГ и ДТГ определяли температуру воспламенения коксового остатка $\left(\mathrm{T}_{\mathrm{i}}\right)$ и температуру выгорания коксового остатка $\left(\mathrm{T}_{\mathrm{b}}\right)$ по методу экстраполяции при пересечении касательных на кривых ТГ и ДТГ. Визуализация методики определения значений $\mathrm{T}_{\mathrm{i}}, \mathrm{T}_{\mathrm{b}}, \mathrm{R}_{\max }$ и $\mathrm{T}_{\max }$ представлена на рис. $1[18,19]$. Температуре $\mathrm{T}_{\max }$ соответствовала максимальная скорость потери массы $\mathrm{R}_{\max }$.

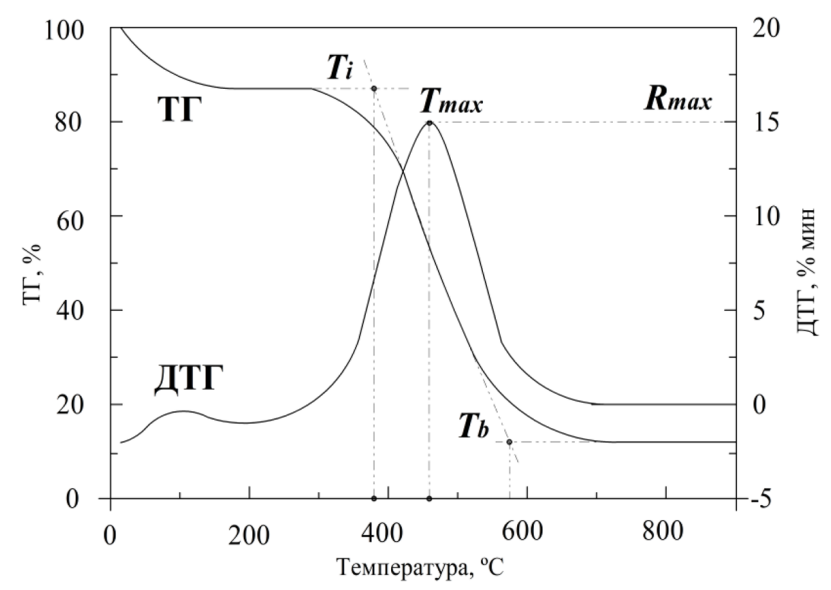

Рис. 1. Определение параметров горения методом экстраполяции кривых

Fig. 1. Determination of combustion parameters by extrapolation of curves 


\section{Результаты и обсуждения}

Горение представляет собой сложный физико-химический процессы, состоящий из трех основных этапов. При нагреве на первом этапе из топливной частицы удаляется влага. Второй этап включает термическое разложение, способствующее воспламенению и горению летучих компонентов топлива. Горение летучих происходит около частицы и за счет теплообмена способствует быстрому прогреву всей частицы, тем самым активируя третий этап - воспламенение и горение коксового остатка, который составляет основную долю тепловыделения. Помимо коксового остатка в топливной частице находится зола, которая остается после сгорания углерода, но чаще всего не оказывает существенного влияния на весь процесс ее сгорания. На параметры воспламенения углеродного остатка влияет ряд факторов, таких как: количество летучих в топливе, влажность топлива, размер топливной частицы, состояние поверхности топливной частицы и др.

Процесс горения частиц ИЗ, ОП и их смесей представлены кривыми ТГ и ДТГ. Потеря массы опилок (рис. 2) происходит в области низких температур, ТГ частиц ИЗ имеет более затяжной характер, основная потеря массы происходит в области более высоких температур. По мере увеличения доли ОП в топливной смеси кривые ТГ смещаются в область более низких температур. По линиям ДТГ изыхского угля (рис. 3) видно, что процесс горения включает один основной этап, воспламенение частиц происходит при температуре $455^{\circ} \mathrm{C}$, максимальная скорость потери массы достигается при температуре $530{ }^{\circ} \mathrm{C}$, а выгорание коксового остатка заканчивается при температуре $542{ }^{\circ} \mathrm{C}$. Высокие температуры воспламенения и выгорания по сравнению с другими образцами (табл. 2) обусловлены сравнительно низким содержанием летучих веществ и высоким содержанием углерода (табл. 1).

Индекс горения ИЗ меньше, чем у ОП. При добавлении 25 \% опилок к ИЗ наблюдается увеличение индекса горения топливной смеси, температура ее воспламенения снизилась на $138{ }^{\circ} \mathrm{C}$, что положительно отразилось на индексе воспламенения, который увеличился на $24^{\circ} \mathrm{C}$. По кривой ТГ и ДТГ на рис. 2 и 3 видны два пика, в первом происходит воспламенение

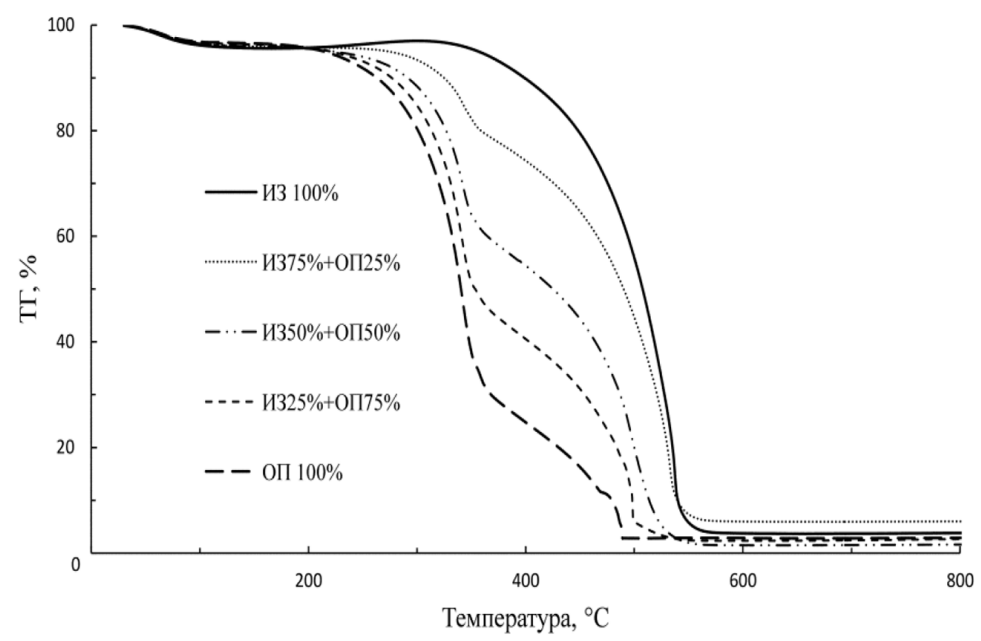

Рис. 2. Кривые ТГ при горении угля ИЗ, опилок ОП и их смесей

Fig. 2. TG curves of Izyhsky coal (Russia), sawdust and their blends 


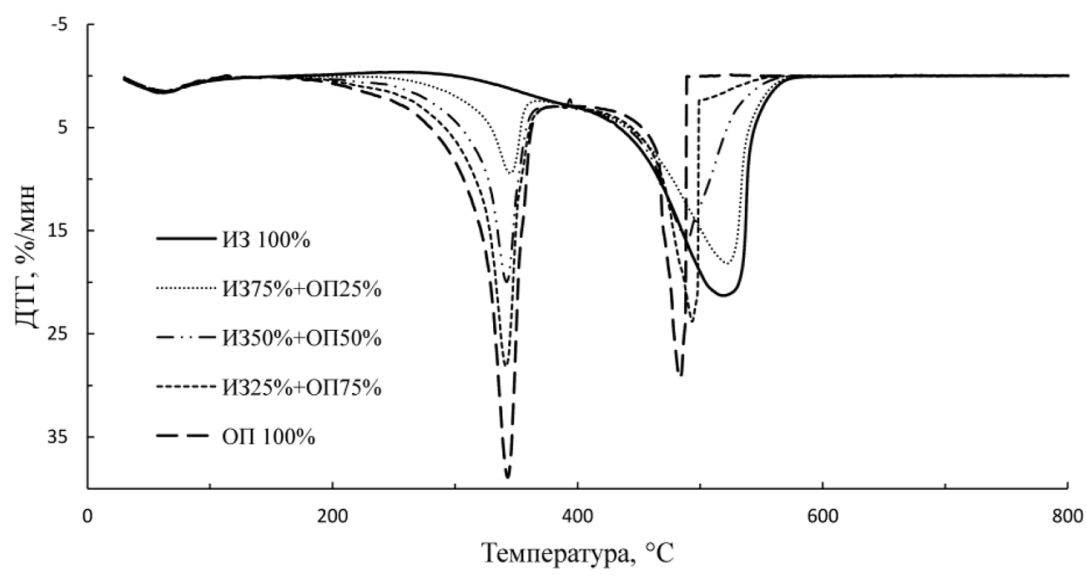

Рис. 3. Кривые ДТГ горения угля ИЗ, опилок ОП и их смесей

Fig. 3. DTG curves of Izyhsky coal (Russia), sawdust and their blends

и горение летучих органических компонентов ОП, второй пик отражает воспламенение и горение коксового остатка ИЗ, что видно при сравнении ее с кривой ИЗ $100 \%$ на рис. 3. При увеличении доли опилок до $50 \%$ и более температура, соответствующая максимальной скорости потери массы, и температура воспламенения перестают изменяться и максимально приближены к $\mathrm{T}_{\max }$ и $\mathrm{T}_{\mathrm{i}}$ опилок.

Кривые на рис. 3 показывают, что процесс горения частиц древесины включает два узких температурных этапа. На первом этапе при температуре $\mathrm{T}_{\mathrm{i}}=308^{\circ} \mathrm{C}$ происходит воспламенение ОП с последующим выгоранием гемицеллюлозы, целлюлозы и части лигнина. На втором этапе сгорает оставшийся лигнин и коксовый остаток $[20,21]$. Раннему воспламенению опилок (при $\left.\mathrm{T}_{\mathrm{i}}=308{ }^{\circ} \mathrm{C}\right)$ способствуют высокое содержание летучих веществ ( $\left.\mathrm{V}^{\mathrm{daf}}=80,2 \%\right)$ и, возможно, благоприятные текстурные характеристики углеродистого вещества (высокая пористость, волокнистая структура), которые отчетливо проявляются на снимках с электронного микроскопа (рис. 4). Индекс воспламенения $\mathrm{D}_{\mathrm{i}}=16 \times 10^{-2}$, индекс выгорания $\mathrm{D}_{\mathrm{b}}=11 \times 10^{-3}$ и индекс горения $\mathrm{S}=4,4 \times 10^{-6}$ отражают высокие показатели горения (табл. 2) в сравнении с другими топливными образцами.

Кривые ТГ и ДТГ на рис. 5 и 6 для угля Ч демонстрируют сходный с углем ИЗ характер горения. Температуры выгорания их углеродных остатков одинаковы, при этом индексы $\mathrm{T}_{\mathrm{i}}$ $\left(422{ }^{\circ} \mathrm{C}\right)$ и $\mathrm{T}_{\max }\left(492{ }^{\circ} \mathrm{C}\right)$ для угля Ч существенно ниже, чем для угля ИЗ, что, по-видимому, обусловлено более высоким выходом летучих веществ.

На кривых ДТГ горения топливных смесей ОП и Ч разного состава на рис. 6 видны два пика. Первый пик, характеризующий горение ОП, увеличивается с увеличением доли ОП в топливной смеси, при этом второй пик, характеризующий горение частиц Ч, уменьшается. Температура воспламенения топливной смеси на основе Ч и ОП немного выше $\mathrm{T}_{\mathrm{i}}$, чем для ОП, и почти не зависит от доли ОП в смеси. Самый низкий индекс горения $\mathrm{S}$, равный $0,9 \times 10^{-6}$, соответствует топливной смеси, состоящей из $75 \%$ Ч и $25 \%$ ОП, а самый высокий $\left(3,4 \times 10^{-6}\right)$ у смеси, состоящей из $25 \%$ Ч и 75 \% ОП. Температура $\mathrm{T}_{\max }$, соответствующая максимальной скорости потери массы, у смесей, содержащих более $25 \%$ ОП, соответствует $\mathrm{T}_{\max }$ для опилок. 


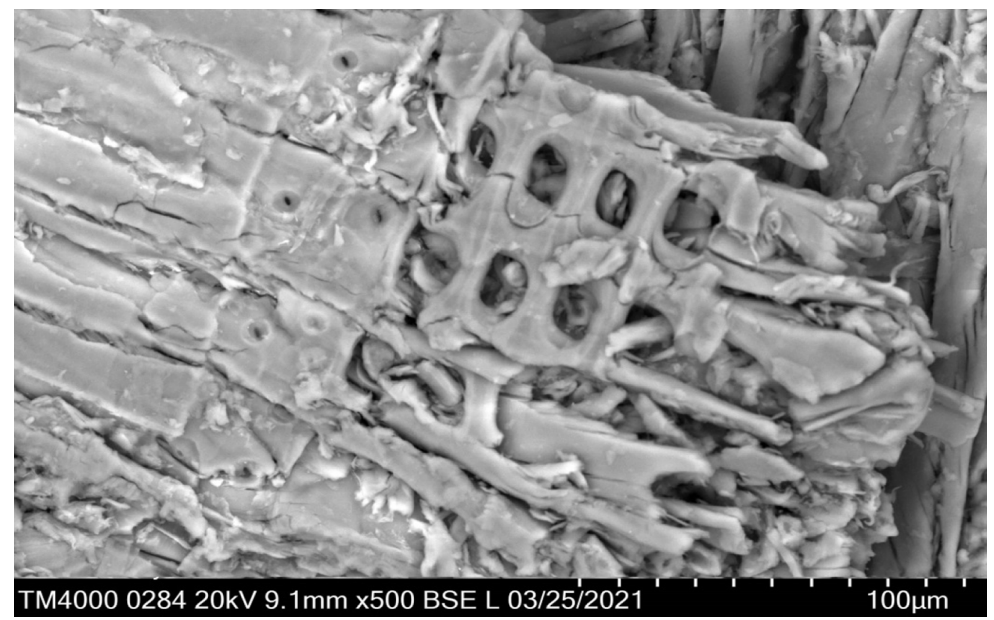

Рис. 4. СЭМ-частицы опилок

Fig. 4. SEM image of sawdust particle

Таблица 2. Характеристики горения топливных образцов

Table 2. Combustion characteristics of fuel samples

\begin{tabular}{|c|c|c|c|c|c|c|c|c|c|}
\hline Образец & $\mathrm{T}_{\mathrm{i}},{ }^{\circ} \mathrm{C}$ & $\mathrm{T}_{\max },{ }^{\circ} \mathrm{C}$ & $\mathrm{T}_{\mathrm{b}},{ }^{\circ} \mathrm{C}$ & $\begin{array}{c}\mathrm{R}_{\max }, \% / \\
\text { мин }\end{array}$ & $\begin{array}{c}\mathrm{R}_{\text {mean }}, \% / \\
\text { мин }\end{array}$ & $\begin{array}{l}\Delta \mathrm{t}_{1 / 2}, \\
\text { мин }\end{array}$ & $\mathrm{D}_{\mathrm{i}} \times 10^{-2}$ & $\mathrm{D}_{\mathrm{b}} \times 10^{-3}$ & $\mathrm{~S} \times 10^{-6}$ \\
\hline ИЗ & 455 & 519 & 542 & 20 & 7,23 & 3,3 & 3,9 & 9,8 & 1,3 \\
\hline $75 \%$ ИЗ+25\% ОП & 317 & 522 & 539 & 18 & 4,70 & 3,0 & 5,1 & 9,7 & 1,6 \\
\hline $50 \%$ ИЗ+50\% ОП & 314 & 342 & 529 & 20 & 5,10 & 1,1 & 8,6 & 4,5 & 2,0 \\
\hline $25 \%$ ИЗ+75\% ОП & 310 & 342 & 504 & 28 & 5,30 & 1,0 & 11,8 & 7,2 & 3,1 \\
\hline 4 & 422 & 492 & 541 & 20 & 4,75 & 3,1 & 4,6 & 11,2 & 1,0 \\
\hline $75 \%$ Ч+25\% ОП & 313 & 482 & 537 & 16 & 3,10 & 2,9 & 4,9 & 9,4 & 0,9 \\
\hline $50 \%$ Ч+50\% ОП & 312 & 343 & 526 & 20 & 4,30 & 1,1 & 8,8 & 4,6 & 1,7 \\
\hline $25 \%$ Ч+75\% ОП & 311 & 343 & 522 & 33 & 5,20 & 1,0 & 14 & 8,1 & 3,4 \\
\hline ОП & 308 & 343 & 490 & 39 & 5,20 & 0,9 & 16 & 11,0 & 4,4 \\
\hline
\end{tabular}

Кривые ДСК теплового потока горения частиц ИЗ, ОП и их смесей представлены на рис. 7. Горение угля выражено одним экзотермическим пиком, при горении опилок и смесей с углем ИЗ наблюдаются два пика, что согласуется с ходом кривых, соответствующих ДТГ. Первый пик отражает горение летучих веществ ОП, второй - лигнина и коксовых остатков. Параметры теплового потока приведены в табл. 3. Интенсивность теплового потока для первого пика почти одинакова для смесей разного состава - около 20 мВ/мг. Тепловой поток для второго пика зависит от состава, самое низкое тепловыделение $\left(66 \mathrm{MB} / \mathrm{мг)} \mathrm{наблюдается} \mathrm{для} \mathrm{смеси,} \mathrm{содержащей} \mathrm{равное} \mathrm{количество} \mathrm{ИЗ} \mathrm{и} \mathrm{ОП.} \mathrm{Температуры} T_{\max }\right.$ первого пика у топливных смесей близки к $T_{\max }$ для ОП.

На кривых ДСК для угля Ч, ОП и смесей (рис. 8) наблюдаются две экзотермы. При добавлении к углю Ч 25 \% ОП происходит увеличение теплового потока в первом и втором экзотер- 


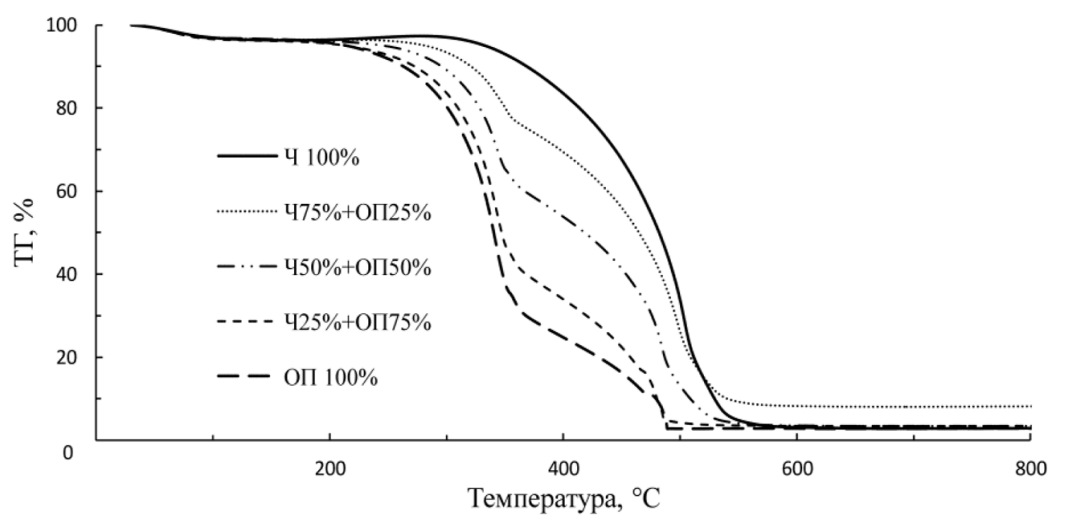

Рис. 5. Кривые ТГ при горении угля Ч, опилок ОП и их смесей

Fig. 5. TG curves of Chernogorsk coal (Russia), sawdust and their blends

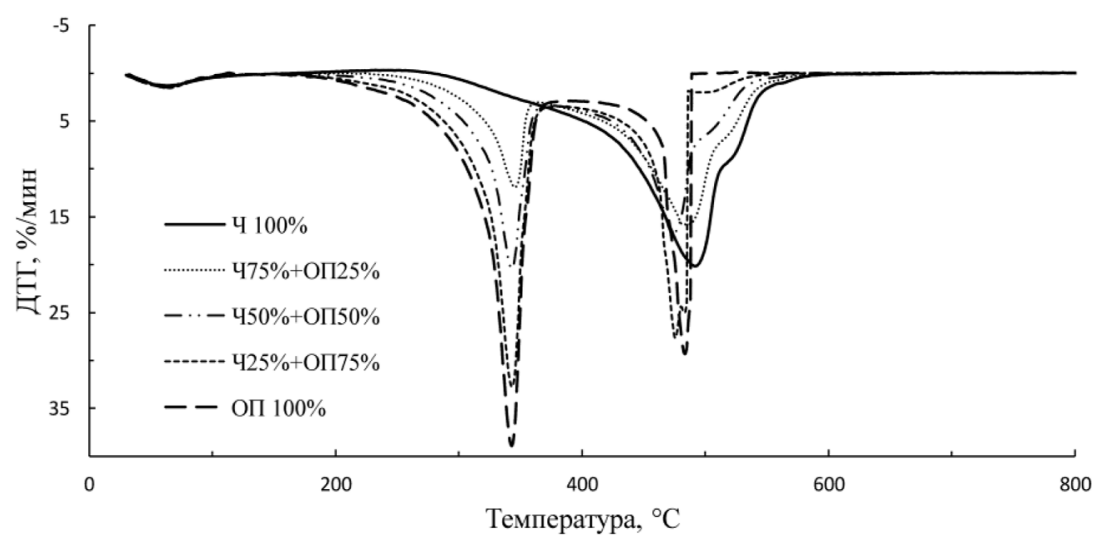

Рис. 6. Кривые ДТГ горения угля Ч, опилок ОП и их смесей

Fig. 6. DTG curves of Chernogorsk coal (Russia), sawdust and their blends

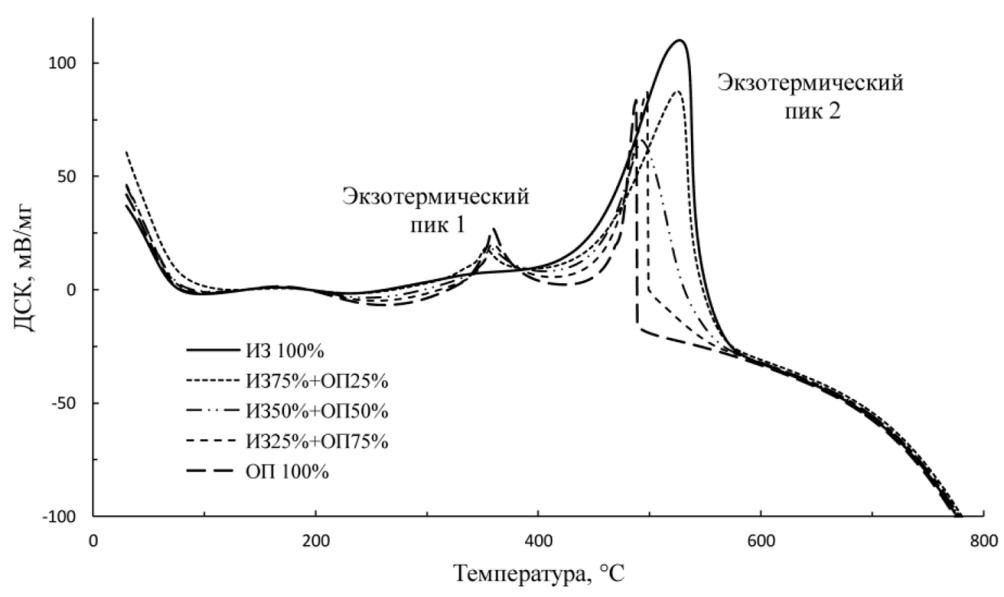

Рис. 7. Кривые ДСК горения фракций ИЗ, ОП и их смесей

Fig. 7. DSC curves of Izyhsky coal (Russia), sawdust and their blends 


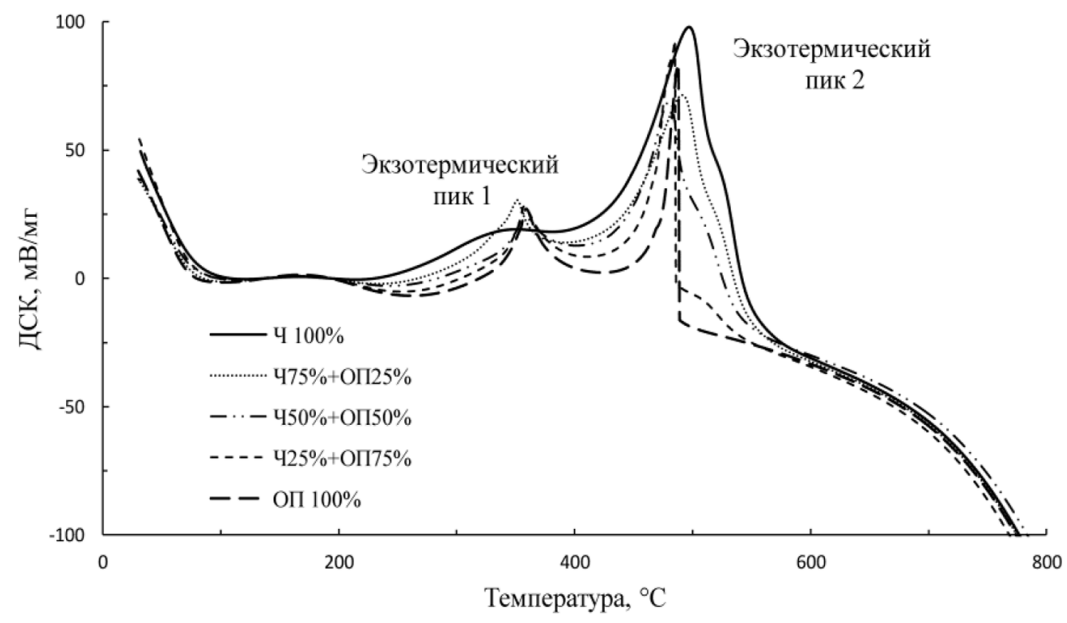

Рис. 8. Кривые ДСК горения фракций Ч, ОП и их смесей

Fig. 8. DSC curves of fraction of Chernogorsk coal (Russia), sawdust and their blends

Таблица 3. Параметры теплового потока при различных соотношениях смеси ИЗ, Ч и ОП

Table 3. Parameters of the heat flow at different proportions of Izyhsky and Chernogorsk coal and sawdust in the blend

\begin{tabular}{|c|c|c|c|c|}
\hline Образец & $\mathrm{Q}_{\text {пик1}}, \mathrm{MB} / \mathrm{M \Gamma}$ & $\mathrm{Q}_{\text {пик2},}, \mathrm{MB} / \mathrm{M \Gamma}$ & $\mathrm{T}_{\text {пик } 1},{ }^{\circ} \mathrm{C}$ & $\mathrm{T}_{\text {пик } 2,}{ }^{\circ} \mathrm{C}$ \\
\hline $100 \%$ ИЗ & - & 110 & - & 527 \\
\hline $75 \%$ ИЗ+25\% ОП & 18 & 88 & 353 & 526 \\
\hline $50 \%$ ИЗ+50\% ОП & 18 & 66 & 358 & 493 \\
\hline $25 \%$ ИЗ+75\% ОП & 20 & 87 & 359 & 498 \\
\hline $100 \%$ Ч & 19 & 97 & 350 & 496 \\
\hline $75 \%$ Ч+25\% ОП & 31 & 71 & 351 & 491 \\
\hline $50 \%$ Ч $+50 \%$ ОП & 25 & 69 & 356 & 480 \\
\hline $25 \%$ Ч+75\% ОП & 28 & 90 & 358 & 486 \\
\hline $100 \%$ ОП & 27 & 86 & 359 & 488 \\
\hline
\end{tabular}

Примечание. $\mathrm{Q}_{\text {пик1 }}$ и $\mathrm{Q}_{\text {пик2 }}-$ тепловой поток для первого и второго экзотермических пиков, $\mathrm{T}_{\text {пик1 }}$ и $\mathrm{T}_{\text {пик } 2}-$ температура первого и второго экзотермических пиков.

мических пиках, при добавлении 50 \% ОП первый и второй экзотермические пики имеют самые низкий тепловой поток. Максимальная температура первого экзотермического пика у всех образцов находится в близком температурном интервале (от 350 до $359{ }^{\circ} \mathrm{C}$ ). Самое высокое тепловыделение во втором экзотермическом пике соответствует топливной смеси, состоящей из $25 \%$ Ч и $75 \%$ ОП.

\section{Заключение}

Проведенное комплексное термогравиметрическое исследование характеристик горения каменных углей и сосновых опилок показало, что в изученных условиях горение углей осу- 
ществляется в пределах одной температурной области с максимумами при $527{ }^{\circ} \mathrm{C}$ для изыхского и $496{ }^{\circ} \mathrm{C}$ для черногорского углей. Горение сосновых опилок, как и смесей с каменными углями, включает две стадии. Добавление опилок в топливную смесь с углями приводит к смещению процесса горения в сторону более низких температур. Температуры воспламенения смесей снижались более чем на $100{ }^{\circ} \mathrm{C}$ за счет увеличения содержания летучих веществ в топливных смесях по сравнению с горением каменных углей по отдельности. По характеристикам горения оптимальны топливные смеси, содержащие 25 \% сосновых опилок в смеси с изыхским углем и 75 \% опилок в смеси с черногорским углем.

\section{Благодарности / Acknowledgement}

Исследование выполнено при финансовой поддержке РФФИ, Правительства Красноярского края и Красноярского краевого фонда науки в рамках научного проекта № 20-48-243001.

The research was funded by RFBR, Krasnoyarsk Territory and Krasnoyarsk Regional Fund of Science, project number 20-48-243001.

\section{Список литературы / References}

[1] Ahn S., Choi G., Kim D. The effect of wood biomass blending with pulverized coal on combustion characteristics under oxy-fuel condition, Biomass \& Bioenergy, 2014, 71, 144

[2] Янковский С.А., Кузнецов Г. В. Особенности физико-химических превращений смесевых топлив на основе типичных каменных углей и древесины при нагреве, XTT, 2019, 1, 26-33 [Yankovsky S. A., Kuznetsov G. V. Physicochemical transformation of mixed fuels based on typical coals and wood upon heating, Solid Fuel Chemistry, 2019, 53, 22-28 (in Russian)]

[3] Росляков П.В., Зайченко М.Н., Мельников Д. А., Верещетин В. A., Attikas R. Использование углей для совместного сжигания с эстонскими сланцами, Теплоэнергетика, 2016, 3, 34-42 [Roslyakov P. V., Zaichenko M.N., Melnikov D. A. et al. Use of coals for co-combustion with Estonian shale oil, Thermal Engineering, 2016, 63(3), 188-196 (in Russian)]

[4] Сосина Д.В., Литуна Д.С., Рыжий И.А., Штегмана А.В., Шапошников Н. А. Опыт сжигания лузги подсолнечника в пылеугольных котлах Кумертауской ТЭЦ, Теплоэнергетика, 2020, 1, 15-22 [Sosin D. V., Litun D. S., Ryzhii I. A. et al. Experience of burning sunflower husks in the Kumertau CHP pulverized coal-fired boilers, Thermal Engineering, 2020, 67(1), 10-16 (in Russian)]

[5] Директор Л.Б., Синельщиков В.А., Сычев Г.А. Теплофизические свойства летучих продуктов низкотемпературного пиролиза древесной биомассы, TBT, 2020, 58(1) 47-50 [Direktor L.B., Sinelshchikov V. A., Sychev, G. A. Thermophysical properties of volatile products of low-temperature pyrolysis of wood biomass, High Temp., 2020, 58, 50-53 (in Russian)]

[6] Ларина О.М., Синельщиков В. А., Сычев Г. А. Термогравиметрический анализ топливных смесей из биомассы и высокозольных углесодержащих отходов, TBT, 2020, 58(5) 782-788 [Larina O.M., Sinelshchikov V.A., Sytchev G.A. Thermogravimetric analysis of fuel blends of biomass and high-ash coal-containing waste, High Temp., 2020, 58, 710-715 (in Russian)]

[7] Vamvuka D., Loukakou E., Avgoustidis C., Stratakis A., Pavloudakis F., Sfakiotakis S. Cocombustion characteristics of lignite/woody biomass blends. Reactivity and fusibility assessment, ENERG SOURCE PART A: Recovery, Utilization, and Environmental Effects, 2019 
[8] Zhou C., Liu G., Wang X., Qi C. Co-combustion of bituminous coal and biomass fuel blends: Thermochemical characterization, potential utilization and environmental advantage, Bioresour. Technol., 2016, 218, 418

[9] Liu X., Chen M., Wei Y. Assessment on oxygen enriched air co-combustion performance of biomass/bituminous coal, Renew. Energy, 2016, 92, 428

[10] Maaten B., Konist A., Siirde A. High-speed thermogravimetric analysis of the combustion of wood and Ca-rich fuel, J. Therm. Anal. Calorim., 2019, 138, 2807

[11] Glushkov D.O., Kuznetsov G. V., Chebochakova D. A., Lyakhovskaya O.E., Shlegel N.E., Anufriev I. S., Shadrin E. Y. Experimental study of coal dust ignition characteristics at oil-free startup of coal-fired boilers, Appl. Therm. Eng., 2018, 142, 371

[12] Wang G., Zhang J., Shao J., Liu Z., Zhang G., Xu T., Guo J., Wang H., Xu R., Lin H. Thermal behavior and kinetic analysis of co-combustion of waste biomass/low rank coal blends, Energy Convers. Manag., 2016, 124, 414

[13] Deng S., Tan H., Wei B., Wang X., Yang F., Xiong X. Investigation on combustion performance and ash fusion characteristics of Zhundong coal co-combustion with coal gangue, Fuel, 2021, 294, 120555

[14] Chen L., Wen C., Wang W., Liu T., Liu E., Liu H., Li Z. Combustion behaviour of biochars thermally pretreated via torrefaction, slow pyrolysis, or hydrothermal carbonisation and co-fired with pulverised coal, Renew. Energy, 2020, 161, 867

[15] Zhang K., Zhang K., Cao Y., Pan W.P. Co-combustion characteristics and blending optimization of tobacco stem and high-sulfur bituminous coal based on thermogravimetric and mass spectrometry analyses, Bioresour. Technol., 2013, 131, 325

[16] Oladejo J.M., Adegbite S., Pang C.H., Liu H., Parvez A.M., Wu T. A novel index for the study of synergistic effects during the co-processing of coal and biomass, Appl. Energy, 2017, 188, 215

[17] Liu H., Gong S., Jia C., Wang Q. TG-FTIR analysis of co-combustion characteristics of oil shale semi-coke and corn straw, J. Therm. Anal. Calorim., 2017, 127, 2531

[18] Zheng S., Hu Y., Wang Z., Cheng X. Experimental investigation on ignition and burnout characteristics of semi-coke and bituminous coal blends, J. Energy Inst., 2020, 93, 1373

[19] Bala-Litwiniak A, Zajemska M. Computational and experimental study of pine and sunflower husk pellet combustion and co-combustion with oats in domestic boiler, Renew. Energy, 2020, 162, 151

[20] Vamvuka D., Tsamourgeli V., Zaharaki D., Komnitsas K. Potential of poor lignite and Biomass blends in energy production, ENERG SOURCE PART A, 2016, 38, 14, 2079

[21] Liang F., Wang R., Jiang C., Yang X., Zhang T., Hu W., Mi B., Liu Z. Investigating cocombustion characteristics of bamboo and wood, Bioresour. Technol., 2017, 243, 556 